\title{
Credit Banking in Business Law Perspective
}

\begin{tabular}{|c|c|c|}
\hline $\begin{array}{r}\text { Faculty of Lay } \\
\text { E-n }\end{array}$ & $\begin{array}{l}\text { Lukmanul Hakim } \\
\text { Universitas Bandar Lar } \\
\text { : lukmanul.hakim@ub }\end{array}$ & Indonesia \\
\hline $\begin{array}{r}\text { How to cite : Lukman Hakim. (2019). Cred } \\
6(1)\end{array}$ & $\begin{array}{l}\text { anking in Business Lau } \\
3-60 \text {. DOI : } 10.25134 / \mathrm{u}\end{array}$ & $\begin{array}{l}\text { pective. UNIFIKASI : Jurn } \\
\text { si.v6i1.1614 }\end{array}$ \\
\hline Submitted : 11-01-2019 & Revised : 31-05-2019 & Accepted : 10-06-2019 \\
\hline
\end{tabular}

\begin{abstract}
The purpose of this study is to encourage an increase in community prosperity, especially in banking legal aspects that can be seen by several things including credit agreements made by banking institutions and customers. In addition, the existence of business risk management has made banking institutions safeguard the health level of the bank so that people continue to believe in the existence of banking institutions. The method in this study uses qualitative analysis which will be given conclusions in accordance with the identification of problems. The results of this study conclude that credit is given to banking institutions in the perspective of business law by using credit agreements as risk mitigation so that non-performing loans will occur which will lead to a decline in bank soundness and the implementation of banking risk management from the perspective of current business law the bank's prudential principle by establishing management operational standards so that banks avoid business risks. The conclusion of this study is that banking institutions must implement procedures in accordance with the standards of each bank so that there will be no legal problems or other business risks. In addition, the application of the precautionary principle must always be applied considering one banking principle is the principle of caution.
\end{abstract}

Keywords : Credit, Bank, Law, Business, Risk.

\section{Kredit Perbankan dalam Perspektif Hukum Bisnis}

\begin{abstract}
Abstrak : Tujuan penelitian ini adalah mendorong peningkatan kemakmuran masyarakat terutama dalam aspek hukum perbankan yang dapat terlihat dengan adanya beberapa hal diantaranya adalah perjanjian kredit yang dibuat oleh lembaga perbankan dan nasabah. Selain itu adanya manajemen risiko bisnis menjadikan lembaga perbankan lebih menjaga tingkat kesehatan bank agar masyarakat tetap percaya akan adanya lembaga perbankan. Metode dalam penelitian ini menggunakan analisis kualitatif yang akan diberikan kesimpulan yang sesuai dengan identifikasi permasalahan. Hasil penelitian ini menyimpulkan mengenai kredit diberikan kepada lembaga perbankan dalam perspektif hukum bisnis dengan menggunakan perjanjian kredit sebagai mitigasi risiko agar tidak terjadi kredit bermasalah yang akan mengakibatkan tingkat kesehatan bank menurun dan serta penerapan manajemen risiko bisnis lembaga perbankan ditinjau dari perspektif hukum bisnis saat ini dengan menerapkan prinsip kehati-hatian bank dengan membuat standar operasional manajemen sehingga bank terhindar dari risiko bisnis. Simpulan dari penelitian ini adalah lembaga perbankan harus menerapkan prosedur sesuai dengan standar dari masing-masing bank sehingga tidak akan terjadi masalah hukum atau risiko bisnis lainnya selain itu penerapan prinsip kehati-hatian harus selalu diterapkan mengingat salah satu azas perbankan adalah adanya Azas kehati-hatian.
\end{abstract}

Kata Kunci : Kredit, Bank, Hukum, Bisnis, Risiko.

\section{INTRODUCTION}

Banking institutions are known as the most regulated institutions by the government, including in Indonesia. Regulatory agencies in Indonesia consist of the Ministry of Finance, Bank Indonesia and the Financial Services Authority. Bank regulations are justified by the desire to maintain a sound and safe financial system to ensure the uniqueness of bank services or services and to increase the greater efficiency mechanism in allocating funds. ${ }^{1}$

Banking institutions besides having business goals also carry out national mandates for the welfare of the masses. Therefore, bank fanfare must not ignore the people's interests, namely mutual prosperity. For this reason, regulation will force banks to act fairly and encourage an increase in the prosperity of

\footnotetext{
${ }^{1}$ Taswan, Manajemen Perbankan : Konsep, Teknik dan Aplikasi, UPP STIM YKPN, Yogyakarta, 2010, Pp. 33
} 
the people. Domination or concentration or monopoly of banking is very contrary to the concept of prosperity equality. ${ }^{2}$

In line with business development, currently banking institutions are institutions that are very closely related to the community because considering all activities carried out by the community will use the services of banks as an intermediary for activities. This bond is reflected in banking activities that are very beneficial to people's lives.

As a financial institution that collects public funds in the form of deposits to then channel them in the form of loans to the public who need sources of funds, roles, and positions of banks that are vital to the economy of a country. ${ }^{3}$

Business and banking activities are activities that involve the interests of various parties and require law as guarantor. One branch of business law is banking law. Where the law is very closely related in banking business activities one of which is in lending to customers.

The need for public funds, will be easier given by the bank if, people who need funds can meet all the requirements provided by the bank. Distributing funds in the form of credit is a very important activity for banks, because banks will get income for the funds channeled. This income can be in the form of interest income for conventional banks, and profit sharing for Islamic banks. The income obtained from the activity of channeling funds to customers is the largest income in each bank, so that the distribution of funds to the community becomes very important for the bank. ${ }^{4}$

In line with the times, especially learning from the history of the development of banking institutions, especially in the perspective of business law where banking institutions do have a very large number of regulations so that the journey to date has made Banking institutions have a good level of health given the existence of a number of regulations governing and the application of banking principles, one of which is the precautionary principle which is the most important principle for banks in providing credit to customers.

As for the subject matter in this study is about how credit is given to banking institutions in the perspective of business law? and how is the application of business risk management to banking institutions reviewed from the perspective of business law ?.

\section{RESEARCH METHODS}

This research is a form of normative juridical research, namely research that is focused on studying the rules or norms as well as the rules in positive law relating to the issues to be discussed. Then, the study of normative law includes the study of: Legal principles; Legal systematics; and legal synchronization. ${ }^{5}$ In this study, there are two main approaches that are used, namely: Legislation Approach (Statute approach), and Conceptual Approach (Conceptual approach), namely:

a. Legislation Approach (Statute approach) ${ }^{6}$ used to examine the rules or legal provisions in accordance with the hierarchy or level of everything related to the Business Activities of Banking Institutions in Indonesia and closely related to the issues to be discussed, especially those related to Business Law and Banking Law.

b. Conceptual approach is used to examine the legal concepts relating to the Business Activities of Banking Institutions in Indonesia, especially in the provision of credit, especially those related to bank credit, whether expressed by experts or in the form of legal doctrine or legal abstraction

\footnotetext{
${ }^{2}$ Ibid

${ }^{3}$ Ismail, Manajemen Perbankan dari Teori menuju aplikasi, Kencana, Jakarta, 2010, Pp. cover

${ }^{4}$ Ibid

5 Zulfi Diane Zaini and Lukmanul Hakim, "Pengawasan Penerapan Prinsip Kehati-Hatian Dalam Pemberian Kredit Perbankanoleh Otoritas Jasa Keuangan”, Volume 3 Issue 1, June 2018, Pp. 58.

${ }^{6}$ Peter Mahmud Marzuki, Penelitian Hukum, Kencana, 2005, Pp. 136.
} 
from a rule related to the Business Activities of Banking Institutions in Indonesia, among others, in bank credit and closely related to the research problems to be discussed.

This study describes the views on legal aspects in banking institutions so that the existence of this research becomes a new reference materialThen conclusions are taken in accordance with the agreement $^{7}$.

\section{RESULTS AND DISCUSSION}

\section{Giving Credit to Banking Institutions in a Business Law Perspective}

Legal aspects are one of the most important aspects in every activity of the community and an institution such as banking, including the activities of lending which is a legal action agreement so that it must be equipped with legal knowledge relating to the provision of credit to the community. Although other aspects outside the law have fulfilled the requirements, but if the legal aspects do not meet the requirements, then they will not be valid. ${ }^{8} \quad$ Banks in carrying out their duties to serve the community cannot be separated from the applicable legal basis. What is done by banking institutions is based on written and unwritten law. Written law in the form of laws and regulations relating to banks, while unwritten law in the form of customary law. ${ }^{9}$

Furthermore, credit managed by the precautionary principle will place good credit quality so that it can provide a large income for the bank. The income earned from credit activities is in the form of a difference between the cost of funds and interest income paid to the credit applicant. ${ }^{10}$ In granting bank loans or financing, it is necessary to pay attention to several matters that have been mandated in Law Number 10 of 1998 concerning Banking must always be guided and apply the principle of prudence. The principle, among others, is manifested in the form of consistent application based on good faith in all requirements and laws and regulations related to the provision of credit by the bank concerned. ${ }^{11}$

The definition of Credit according to Article 1 number 12 of Act Number 7 of 1992 concerning Banking is as follows: Credit for provision of money or equivalent claims, based on an agreement or agreement between banks and other parties that requires the borrower to repay the debt after a certain period of time with the amount of interest, compensation, or distribution of profit.

Whereas the definition of credit according to article 1 number 11 of Act Number 10 of 1998 concerning Banking undergoes a few changes, namely as follows: the availability of money or bills that can be equated with it, based on an agreement or agreement between banks and other parties that require the borrowing to pay off the debt after a certain period of time.

In the development of modern banking the notion of credit is not limited to borrowing only from customers or traditional credit, but more broadly and the flexibility of credit given. ${ }^{12}$ In granting credit, banks must pay attention to the principles of lending, including the Prudential Principle.

Every credit provision must be carried out carefully to provide assurance that proper credit is given and mitigate risks, including analyzing before credit is terminated and monitoring credit. In order for credit to be of high quality, it must be analyzed so that credit risk can be anticipated from the start of the loan. The credit provided must be in accordance with the needs of the debtor and it is believed that

\footnotetext{
${ }^{7}$ Agus Surachman, "Kritik Terhadap Undang Undang Nomor 25 Tahun 2007 Tentang Penanaman Modal (Perspektif Teori Hukum)", Jurnal Unifikasi, volume 05 nomor 01, januari 2018, pp. 25

${ }^{8}$ Sutarno, Aspek-aspek hukum perkreditan pada bank, Alfabeta, Bandung, 2009, Pp. 3

${ }^{9}$ Gatot Supramono, Perbankan dan masalah kredit suatu tinjauan di bidang yuridis, Rineka Cipta, Jakarta, 2009, Pp. 46

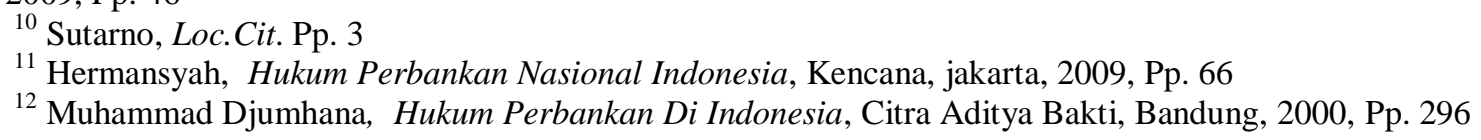


credit can be returned by the debtor at the time and amount expected by the bank. In evaluating credit, the bank evaluates prospective debtors with the $5 \mathrm{C}$ principle, namely the bank's confidence in aspects of character, capital, capacity, collateral, condition of economy and collateral which can be explained as follows:

a. Character, which is the bank's assessment of the character of the prospective debtor so that the bank can conclude that the debtor is honest, has good intentions and will not complicate the bank in the future. Before giving credit, the bank must know the prospective debtor first, especially the character.

b. Capacity, which is the bank's assessment of the ability of prospective debtors in their business fields and / or debtor's management capabilities, so that the bank believes that the business to be financed with the credit is managed by the right people.

c. Capital, namely the bank's assessment of the financial position of the prospective debtor as a whole, including the debtor's cash flow, both for the past and the projections in the future, so that the debtor's capital capability can be known in supporting project financing for the business concerned.

d. Condition of Economy, which is the bank's assessment of market conditions in the country and abroad, both past and future, so that the marketing prospects can be known from the results of the debtor's business financed by credit from the bank.

e. Collateral, which is the bank's assessment of collateral valued by prospective debtors. Collateral is tangible and intangible objects that are granted rights and power by prospective debtors to the bank to guarantee repayment of debtors' debts, if the credit they receive cannot be repaid in accordance with the time agreed in the credit agreement or addendum. The collateral is very important as a last resort for credit settlement, if the debtor is unable to fulfill the obligation to pay the principal and interest. ${ }^{13}$

Banks as credit providers compete openly in offering credit services. The Bank not only innovates by providing various facilities and prizes, but now the bank uses a strategy in attracting superior customers by getting customers from other banks who have a good credit track record, so that the bank has quality customers and minimizes the possibility of bad credit. . The method used by banks in attracting and obtaining good quality customers is by persuading customers from other banks to become customers or by making credit transfers, better known as take over credit.

A bank as a creditor, one of the components used to safeguard its interests when distributing credit is the possession of collateral objects (material rights) submitted by the debtor. One method of mastering collateral by banks, namely by taking over credit that has previously made a loan agreement with another bank, along with guarantees that accompany the closing of the credit agreement. Take over is a term used in the banking sector in the event that a third party gives credit to a debtor who aims to pay off debtor's debt / credit to the initial creditor and give new credit to the debtor so that the position of this third party replaces the position of the initial creditor and becomes new bank customers (take over) with fees obtained from a new bank. Furthermore, in the perspective of business law where credit has an agreement that is often called a credit agreement, in which the credit agreement has a legal relationship between the parties including creditors and debtors so that this agreement often becomes a reference and legal source for the parties who make it. Assessing social phenomena about law when viewed from various points of view will provide different interpretations of one object problem. ${ }^{14}$

In addition, in providing small business loans, banks also require guarantees. As the main guarantee is the value and feasibility of the business that will be financed with the credit requested. If

\footnotetext{
${ }^{13}$ Maryanto Supriono, Buku Pintar Perbankan, Yogyakarta: Andi Yogyakarta, 2012. Pp. 75.

${ }^{14}$ Saifullah, Refleksi Sosiologi Hukum, Refika Aditama, Bandung, 2010, Pp. 5
} 
the value and feasibility of a bank's business do not guarantee the return of credit, the bank requires that it guarantee the return of credit in the form of material guarantees. ${ }^{15}$

Own guarantee in the perspective of business law or banking law is one of the objects that are used as dependents in the form of money loans, in addition, guarantees are usually given to creditors to fulfill obligations that can be assessed with money arising from an agreement.

Based on the description above, it can be concluded that credit in the perspective of business law is closely related to the fulfillment of collateral as a prerequisite or can be said as a form of prudential banking institutions so that banking institutions can maintain bank soundness so that people continue to grow and continue to believe provide funds to banking institutions.

\section{The Implementation of Business Risk Management in Banking Institutions Is Viewed From a Business Law Perspective}

The monetary crisis that attacked the Indonesian economy in 1997 eroded the porous modern banking sector because the capitalistic sector was too dependent on foreign capital. The increase in foreign debt, both government and private debt, makes the Indonesian economy increasingly difficult because the recipe for economic restructuring (debt, revocation of subsidies, and privatization) the International Monetary Fund (IMF) does not strengthen, but weakens people's economic resilience. ${ }^{16}$

With these conditions so that banking institutions must be able to see the risks that exist so that they can avoid the Non Performance Loan (NPL) and increase the application of the precautionary principle as a way to manage the risk of lending to debtors.

In connection with the application of prudential banking principles or known as the prudential banking principle in order to regulate the traffic of banking activities, one of the efforts so that this principle can be applied is the principle of knowing customers. ${ }^{17}$ The development of the banking world is so complex, with various types of products and business systems in various competitive advantages. This complexity has created a new system and competitor in the banking world, not only between banks but also between banks and financial institutions. A real phenomenon that has demanded bank financial managers to be more anticipatory towards changes that occur in the world of banking. ${ }^{18}$

In a business, there must be a risk, including those experienced by banking institutions, especially non-performing loans that can lead to bad credit going forward. The symptoms of problem loans are as follows:

Symptoms of problem loans are:

1. There is a decrease in the debtor's financial condition which is evident from the late payment.

2. There is an act from the debtor who begins to be less cooperative by starting to delinquent and not paying on time.

3. The existence of submission of data or information and reports that are incorrect or have absolutely no reports.

4. There is a decrease in the value and quality and quantity of assets and collateral specified in the agreement.

5. There is a change of management without the approval of the creditor, both position, shareholders and important positions.

15 Arisson Hendry, Et, al, Perbankan Syariah Perspektif Praktisi, Muamalat Institute, Jakarta, 1999, Pp. 67

${ }^{16}$ Sarip dan Diana Fitriana, Legal Antropology Approach on the Application of Village Website in Digital Economic Era in Indonesia, UNIFIKASI : Jurnal Ilmu Hukum, Volume 05 Nomor 02, July 2018, Pp 102

${ }^{17}$ Lukmanul Hakim dan Eka Travilta Oktaria, "Prinsip kehati-hatian pada lembaga perbankan dalam pemberian kredit, Jurnal Keadilan Progresif”, Vol 9 No 2 September 2018, Pp 165.

${ }^{18}$ H. As. Mahmoedin, Etika Bisnis Perbankan, Penerbit Mulia Sari, Jakarta, 1994, Pp. 32 
6. There is a personal or family sale that is brought into the company or a problem between the management.

7. There is a claim from within the company itself or from outside the company.

8. There are problems with labor or labor that disrupt the stability of the company. ${ }^{19}$

Risk management is not only needed in the banking world. But it can also be applied in various fields of business or activity. Each field has a variety of risk factors. In banking, risk management is very crucial because the risk factors that emerge can come from a variety of factors, as well as the definition of risk which is only limited to future losses. Therefore the application of risk management in banks is expected to control the risks and losses that might occur.

The implementation of risk management in banks will increase shareholder value, provide information to bank managers on the possibility of future losses, improve methods and systematic decision making based on available information. This information is used as a basis in measuring bank performance that is more accurate, assessing the risks of bank business activities, and creating a strong risk management infrastructure to improve bank competitiveness. As for the banking supervision authority, the implementation of risk management will make it easier to assess in terms of the risk of losses faced by banks that can affect capital, as well as a basis for assessing the strategy and supervision of banks.

The higher level of financing in a bank is also accompanied by a large credit risk. This credit risk must be minimized so that the bank can maintain its business continuity. One way to minimize credit risk is to procure a control that consists of several policies and procedures designed to carry out financial management functions safely, objectively and in accordance with applicable banking regulations.

In simple terms it can be said that banks that maintain existing business risks or are able to minimize business risks can be said to be healthy banks. Banks are required to fulfill or maintain their level of health so that they can carry out business activities properly, especially by maintaining Non-Performing Loans such as non-performing loans or even to bad credit.

In other words, a healthy bank is a bank that can maintain and maintain the level of public trust, can carry out the intermediary function, can help smooth the traffic of payments and can be used by the government in implementing various policies, especially monetary policy. ${ }^{20}$

The global financial crisis even an increase in the rupiah against the dollar some time ago provides a valuable lesson that innovation in banking products, services, and activities that are not balanced with the application of adequate risk management can lead to a variety of fundamental problems with the bank and the financial system as a whole. maintain the level of health and public trust.

Regarding the implementation of banking risk management Simply stated is the implementation of management functions in risk mitigation, especially the risks faced by corporate organizations, families, and society. Thus risk management includes activities in planning, organizing, compiling, leading and overseeing risk management programs. ${ }^{21}$

Risk management programs include the following tasks:

a). identify the risks faced,

b). measure or determine the amount of risk,

c). looking for ways to deal with or overcome risks,

d). develop strategies to minimize or control risk,

\footnotetext{
${ }^{19}$ Irman, Tb, Anatomi Kejahatan Perbankan, Penerbit AYYCCS Group, Jakarta 2006, Pp. 147

20 Allen, L. and T.G. Bali, 2007, "Cyclicality in Catastrophic and Operational Risk Measurement". Journal of Banking and Finance. vol. 31 no. 1, pp. 1191-1235

${ }^{21}$ Bramantyo Djohanputro, Restrukturisasi Perusahaan Berbasis Nilai. Jakarta. PPM, 2004, Pp 67
} 
e). and coordinate the implementation of risk mitigation and evaluate risk management programs that have been made.

According to Bank Indonesia Regulation Number 11/25 / PBI / 2010 concerning Amendments to PBI Number 5/8 / PBI / 2003 concerning Application of Risk Management, Risk is the potential loss due to the occurrence of certain events and Risk Management is a series of methodologies and procedures used to identify, measure, monitor and control risks arising from all bank business activities.

The application of risk management to banking institutions can use various alternative risk profile assessments. Besides that, improving the bank's business performance has also become a necessity according to Bank Indonesia regulations Number 5/2 / DPNP / 2003. Management of business risk profiles in the process of implementing risk management in Indonesian banking is certainly not easy to do. Furthermore, another problem that often arises is how to manage risk management at the bank so that the banking intermediary function remains consistent and integrated.

Based on the description above, it can be concluded that banking business risk management in a business perspective can be seen in the health care of these banking institutions so that the satisfaction or trust of the public is maintained and people continue to be able to trust funds in banking institutions.

\section{CONCLUSION}

Based on the Results of the Analysis Above, Conclusions can be Taken as Follows:

1. Giving Credit to Banking Institutions In this Business Law Perspective can be seen by the application of the 5C principle and guarantee to the debtor so that the debtor can maintain the credit that has been given so that it does not cause problems such as the existence of bad credit so that credit can continue profit without dispute.

2. Application of Banking Institutions Business Risk Management Viewed from Business Law here can be seen in improving bank performance by tackling risks that exist as minimum as possible and can monitor or control all types of risks of bank business activities so as not to cause problems and people continue to believe.

\section{SUGGESTION}

Banking credit must be able to be used properly considering that the funds available from banking institutions are funds from the community besides that the bank must also maintain its level of health from the existing risks such as the presence of bad credit or perhaps other risks that can result in banks not being profitable.

\section{REFERENCES}

\section{Books}

Arisson Hendry, Et, al. 1999. Perbankan Syariah Perspektif Praktisi, Muamalat Institute, Jakarta.

Bramantyo Djohanputro. 2004. Restrukturisasi Perusahaan Berbasis Nilai. Jakarta. PPM.

Gatot Supramono. 2009. Perbankan dan masalah kredit suatu tinjauan di bidang yuridis, Rineka Cipta, Jakarta.

Hermansyah. 2009. Hukum Perbankan Nasional Indonesia, Kencana, Jakarta.

H. As. Mahmoedin. 1994. Etika Bisnis Perbankan, Penerbit Mulia Sari, Jakarta.

Ismai. 2010., Manajemen Perbankan dari Teori menuju aplikasi, Kencana, Jakarta.

Irman, Tb. 2006. Anatomi Kejahatan Perbankan, Penerbit AYYCCS Group, Jakarta.

Muhammad Djumhana. 2000. Hukum Perbankan di Indonesia, Citra Aditya Bakti, Bandung.

Maryanto Supriono. 2012. Buku Pintar Perbankan, Yogyakarta: Andi Yogyakarta.

Peter Mahmud Marzuki. 2005. Penelitian Hukum, Kencana. Jakarta.

Sutarno. 2009. Aspek-Aspek Hukum Perkreditan Pada Bank, Alfabeta, Bandung. 
Saifullah. 2010. Refleksi Sosiologi Hukum, Refika Aditama, Bandung.

Taswan. 2010. Manajemen Perbankan : Konsep, Teknik dan Aplikasi, UPP STIM YKPN, Yogyakarta.

\section{Journals}

Agus Surachman. 2018. “ Kritik Terhadap Undang Undang Nomor 25 Tahun 2007 Tentang Penanaman Modal (Perspektif Teori Hukum)”, Jurnal Unifikasi, volume 05 nomor 01, Januari 2018.

Allen, L. and T.G. Bali, 2007. "Cyclicality in Catastrophic and Operational Risk Measurement". Journal of Banking and Finance. vol. 31 no. 1, pp. 1191-1235

Sarip and Diana Fitriana. 2018. "Legal Antropology Approach on the Application of Village Website in Digital Economic Era in Indonesia", UNIFIKASI : Jurnal Ilmu Hukum, Volume 05 Nomor 02, July 2018.

Lukmanul Hakim and Eka Travilta Oktaria. 2018. “ Prinsip kehati-hatian pada lembaga perbankan dalam pemberian kredit” Jurnal Keadilan Progresif, Vol 9 No 2 September 2018.

Zulfi Diane Zaini and Lukmanul Hakim. 2018. "Pengawasan Penerapan Prinsip Kehati-Hatian Dalam Pemberian Kredit Perbankanoleh Otoritas Jasa Keuangan”, Jurnal Keadilan Progresif. Volume 9 Issue 1, June 2018.

\section{Legislations}

Indonesia, Undang-Undang Dasar Negara Republik Indonesia Tahun 1945

Undang-Undang Nomor 7 Tahun 1992 tentang Perbankan Jo Undang-Undang Nomor 10 Tahun 1998 tentang Perbankan.

Peraturan Bank Indonesia Nomor 11/25/PBI/2010 mengenai Perubahan atas PBI Nomor 5/8/PBI/2003 tentang Penerapan Manajemen Risiko 